\title{
NADPH Oxidase Mediates Depressive Behavior Induced by Chronic Stress in Mice
}

\author{
Ji-Seon Seo, ${ }^{1}$ Jin-Young Park, ${ }^{1}$ Juli Choi, ${ }^{1}$ Tae-Kyung Kim, ${ }^{1,2}$ Joo-Hyun Shin, ${ }^{3}$ Ja-Kyeong Lee, ${ }^{3}$ and Pyung-Lim Han ${ }^{1,2}$ \\ ${ }^{1}$ Department of Brain and Cognitive Sciences, Ewha Womans University, Seoul 120-750, Republic of Korea, ${ }^{2}$ Department of Chemistry and Nano Science, \\ Ewha Womans University, Seoul 120-750, Republic of Korea, and '3Department of Anatomy, Inha University School of Medicine, Inchon 400-712, Republic \\ of Korea
}

Stress is a potent risk factor for depression, yet the underlying mechanism is not clearly understood. In the present study, we explored the mechanism of development and maintenance of depression in a stress-induced animal model. Mice restrained for $2 \mathrm{~h}$ daily for $14 \mathrm{~d}$ showed distinct depressive behavior, and the altered behavior persisted for $>3$ months in the absence of intervention. Acute restraint induced a surge of oxidative stress in the brain, and stress-induced oxidative stress progressively increased with repetition of stress. In vitro, the stress hormone glucocorticoid generated superoxide via upregulation of NADPH oxidase. Consistently, repeated restraints increased the expression of the key subunits of NADPH oxidase, p47phox and p67phox, in the brain. Moreover, stressed brains markedly upregulated the expression of p47phox to weak restress evoked in the poststress period, and this molecular response was reminiscent of amplified ROS surge to restress. Pharmacological inhibition of NADPH oxidase by the NADPH oxidase inhibitor apocynin during the stress or poststress period completely blocked depressive behavior. Consistently, heterozygous p47phox knock-out mice $\left(p 47 p h o x^{+/-}\right)$ or molecular inhibition of p47phox with Lenti shRNA-p47phox in the hippocampus suppressed depressive behavior. These results suggest that repeated stress promotes depressive behavior through the upregulation of NADPH oxidase and the resultant metabolic oxidative stress, and that the inhibition of NADPH oxidase provides beneficial antidepression effects.

\section{Introduction}

Depression is a psychiatric pandemic imposing cognitive and emotional symptoms, including depressed mood and disability in social life. However, its pathophysiology is poorly understood (Krishnan and Nestler, 2008). Human depression has a heterogeneous etiology, so underlying mechanisms appear to be diverse and complex. Recent studies in stress-induced animal models, which do not presume or exclude the possibility that depression is caused by the depletion of monoaminergic activity, have shed light on the basis of depression, although stress-based animal models might mimic stress-triggered depression in humans (Pittenger and Duman, 2008; Nestler and Hyman, 2010). Administration of stressful constraints for $10-14 \mathrm{~d}$ in rodents produces depressive behavior (Berton et al., 2006; Kim and Han, 2006; Covington et al., 2009; Kim et al., 2012). Among important changes in the brain of stress-induced animal models, accumulation of oxidative stress has been noted (Reagan et al., 2000; Madrigal et al., 2001; Sahin and Gümüşlü, 2004; Tsiakitzis et al., 2005;

Received Feb. 19, 2012; revised April 22, 2012; accepted May 18, 2012.

Author contributions: J.-S.S. and P.-L.H. designed research; J.-S.S., J.-Y.P., J.C., T.-K.K., J.-H.S., and P.-L.H. performed research; J.-H.S., J.-K.L., and P.-L.H. contributed unpublished reagents/analytic tools; J.-S.S., J.-Y.P., J.C., T.-K.K., J.-K.L., and P.-L.H. analyzed data; J.-S.S., J.-Y.P., J.C., T.-K.K., J.-K.L., and P.-L.H. wrote the paper.

This research was supported by a grant (2010K000814) from Brain Research Center, The 21st Century Frontier Research Program of the Ministry of Education, Science and Technology, Republic of Korea.

The authors declare no competing financial interests.

Correspondence should be addressed to Pyung-Lim Han, Ph.D., Department of Brain and Cognitive Sciences, Ewha Womans University, 11-1 Daehyun-Dong, Seodaemoon-Gu, Seoul 120-750, Republic of Korea. E-mail: plhan@ewha.ac.kr.

DOI:10.1523/JNEUROSCI.0794-12.2012

Copyright $\odot 2012$ the authors $\quad 0270-6474 / 12 / 329690-10 \$ 15.00 / 0$
Zafir and Banu, 2009). Excess levels of reactive oxygen species (ROS), including superoxide and hydroxyl radicals, can damage cellular components and induce functional abnormalities in many cell types (Halliwell, 2006). Chronic stress alters the expression of genes regulating antioxidant systems, such as superoxide dismutases (SODs), catalase, glutathione peroxidase, glutathione reductase, and NADPH oxidase (Grillo et al., 2003; Linares et al., 2007; Schiavone et al., 2009). Moreover, treatment with glucocorticoid (GC; cortisol in humans and corticosterone in rodents) alone increases ROS both in vitro and in the brains of animals, while also downregulating various antioxidant enzymes (McIntosh et al., 1998; Lee et al., 2009; Sato et al., 2010) and inducing depression-like behavior (Zhao et al., 2008). However, researchers have been unable to pinpoint the mechanisms that enable behavioral stress to cause depression.

NADPH oxidase is a membrane-bound enzyme complex composed of six subunits, including three cytosolic subunits (p47phox, p67phox, and p40phox), two membrane subunits [gp91phox (NOX) and p22phox] and Rho GTPase. To ensure enzymatic activity, p47phox is phosphorylated, which in turn triggers assembly of a functional complex at the membrane (Bedard and Krause, 2007). NADPH oxidase transfers an electron from NADPH to molecular oxygen to produce $\mathrm{H}^{+}$and superoxide (Bedard and Krause, 2007). Superoxide is rapidly dismutated by SODs to hydrogen peroxide $\left(\mathrm{H}_{2} \mathrm{O}_{2}\right)$, which is then converted to water and oxygen by the glutathione peroxidase-glutathione reductase system, or by the peroxiredoxin 3-thioredoxin 2-thioredoxin reductase-2 system, at the expense of glutathione/NADPH (Rhee et al., 2005; Temple et al., 2005; Buettner, 2011). In the present study, complementary 

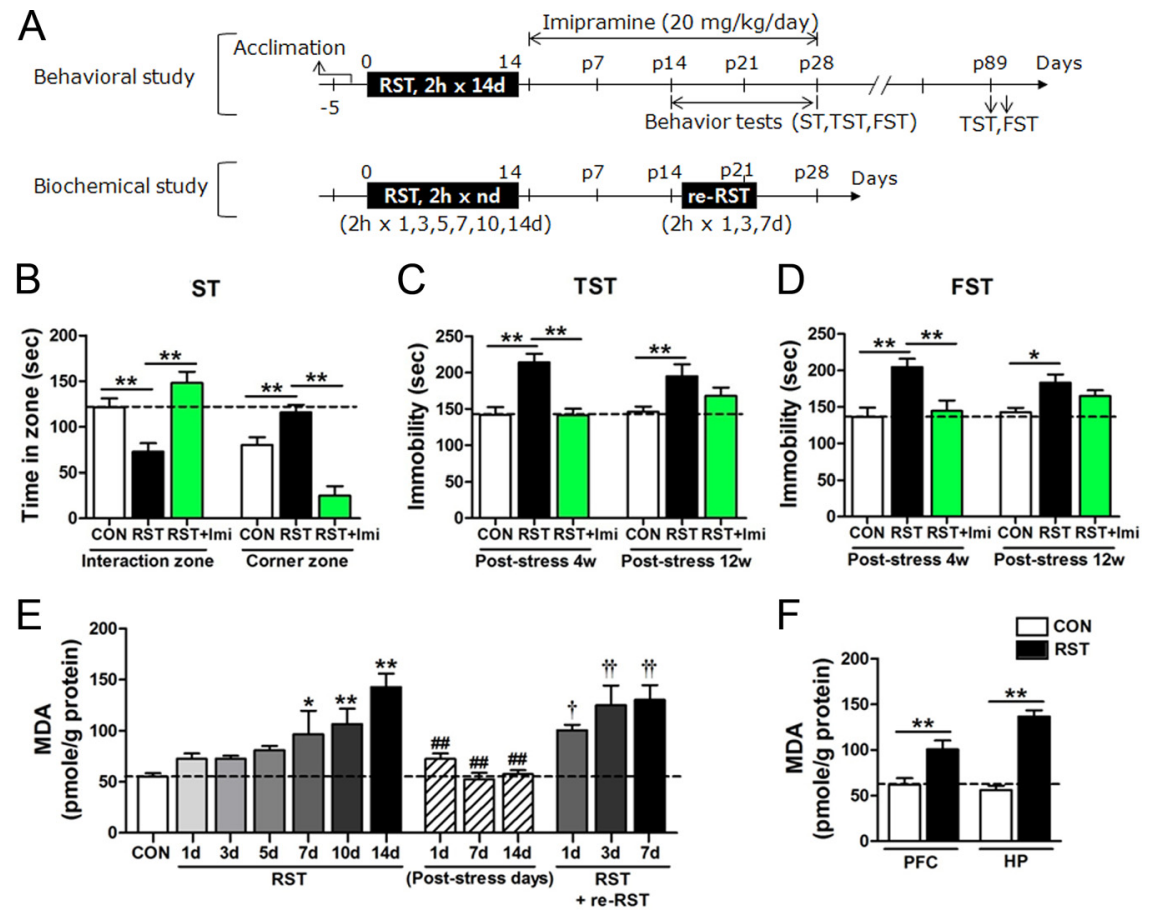

Figure 1. Repeated stress promoted lasting behavioral changes and increased oxidative stress in the brain. $\boldsymbol{A}$, Experimental design for treatment with $2 \mathrm{~h} \times 14 \mathrm{~d}$ restraint and behavioral/biochemical assessments. Restress was given with $2 \mathrm{~h}$-restraint for indicated days. RST, restraint. $\boldsymbol{B}$, Behavioral performance in the social interaction test. Time spent in the interaction zone and corner zones ( $n=9-11$ animals). One-way ANOVA and Newman-Keuls post hoc test $\left[F_{(2,27)}=13.70, p<0.0001\right.$ for the interaction zone; $F_{(2,27)}=25.51, p<0.0001$ for the corner zone]. RST, mice treated with $2 \mathrm{~h} \times 14 \mathrm{~d}$ restraint; RST + Imi, mice treated with RST and imipramine. ST, sociability test; $C O N$, control. C, D, Immobility time in the tail suspension test ( ) and forced swim test (D) on poststress days $28-29$ (poststress $4 \mathrm{w}$ ) and poststress days $89-90$ (poststress $12 \mathrm{w}$ ) ( $n=8$ animals for each group, each time). Two-way repeated-measures ANOVA and Bonferroni post hoc test; significant difference among groups in TST $\left[F_{(2,21)}=13.94\right.$, $p=0.0001]$ and $\operatorname{FST}\left[F_{(2,21)}=12.35, p<0.001\right]$, and no interaction between restraint or imipramine with time $\left[F_{(2,21)}=2.373\right.$, $p=0.1177$ in TST; $F_{(2,21)}=2.005, p=0.1597$ in FST]. $\boldsymbol{E}$, MDA levels in the hippocampus after treatment with restraint for indicated days (control, $n=12$; RST group, $n=6-9$; poststress group, $n=8$; re-RST group, $n=8$ ). One-way ANOVA and Newman-Keuls post hoc test $\left[F_{(6,49)}=9.220, p<0.0001\right.$ for RST groups; $F_{(3,26)}=29.78, p<0.0001$ for groups marked with the poststress period; and $F_{(3,28)}=7.128, p<0.01$ for re-RST groups]. $\boldsymbol{F}$, MDA levels in the hippocampus and prefrontal cortex after treatment with the $2 \mathrm{~h} \times 14 \mathrm{~d}$ restraint $(n=6-8)$. Tw0-way ANOVA and Bonferroni post hoc test; significant effect of RST $\left[F_{(1,22)}=65.13, p<0.0001\right]$, no significant effect of different brain regions $\left[F_{(1,22)}=4.206, p=0.0524\right]$, and significant interaction between RST and brain-region $\left[F_{(1,22)}=7.989, p<0.01\right]$. One-way ANOVA and Newman-Keuls post hoc test; significant difference in stress effects between hippocampus and prefrontal cortex $\left[F_{(3,22)}=28.19, p<0.0001\right]$. Data are presented as the means $\pm S E M .^{*}$ and ${ }^{* *}$, differences between the indicated groups or from the control; \# and \#\#, differences from the fourteenth RST group; $†$ and $+\dagger$, difference from the poststress day 14 group, at $p<0.05$ and $p<0.01$, respectively.

molecular, pharmacological, and genetic analyses demonstrated that repeated restraint promotes depression-like behavior through the GC-dependent upregulation of NADPH oxidase, while the inhibition of NADPH oxidase suppresses the induction and maintenance of depressive behavior.

\section{Materials and Methods}

Animals. Male 7-week-old C57BL/6 mice were purchased from Daehan BioLink. Mice carrying a designed mutation at the p47phox gene (Huang et al., 2000) were obtained from The Jackson Laboratory and were maintained by back-crossing with C57BL/6J mice. For genotyping, tail genomic DNA was obtained, and PCR was performed using the primers 5' -TGGAAGAAGCTGAGAGTTGAGG-3' and 5'-TCCAGGAGCTTATGAATGACC-3. After digestion with MspI, 160 bp was obtained for wild type $(+/+)$, and 160, 102, and $58 \mathrm{bp}$ were obtained for heterozygotes $(+/-)$. Male $\mathrm{p} 47$ phox mice $7-12$ weeks of age were used in behavioral tests. Mice were housed in pairs in a standard clear plastic cage in a temperature-controlled and humiditycontrolled environment for 1 week before the start of experiments. All animals were handled in accordance with the animal care guidelines of the Ewha Womans University School of Medicine.
Restraint stress. The restraint treatment used in this study was performed as previously described (Kim and Han, 2006; Seo et al., 2011). In brief, mice were individually placed headfirst into well ventilated $50 \mathrm{ml}$ polypropylene conical tubes, which were then plugged with a 3-cm-long middle tube, and finally tied with a cap of the $50 \mathrm{ml}$ tube. After each session of restraint, the animals were returned to their home environment, in which they were housed in pairs in normal plastic cages with free access to food and water.

Corticosterone measurement. Corticosterone levels in the brain tissues were measured as described previously (Graham et al., 2011), with a modification. Briefly, mice were killed and perfused with saline $(0.9 \% \mathrm{NaCl})$. Hippocampi from two animals were pooled and stored frozen $\left(-70^{\circ} \mathrm{C}\right)$ until used. Tissue samples were weighed (average, 0.02-0.03 g) and homogenized in $200 \mu \mathrm{l}$ of ice-cold $0.01 \mathrm{M}$ Tris- $\mathrm{HCl}$, $0.15 \mathrm{M} \mathrm{NaCl}, \mathrm{pH} 7.4$ (0.1 M TBS). Then, ice-cold $100 \%$ ethyl acetate was added at the ratio of TBS/ethyl acetate, $1: 2.5$, and incubated for 30 min at $4^{\circ} \mathrm{C}$ on an orbital shaker. To gain the steroid layer, samples were centrifuged at 8000 $\mathrm{rpm}$ at $4^{\circ} \mathrm{C}$ for $10 \mathrm{~min}$, the top layer $(\sim 400 \mu \mathrm{l})$ was collected and stored at $-70^{\circ} \mathrm{C}$ until measurement. Corticosterone levels in tissue samples were measured in duplicate using an enzyme immunoassay (EIA) kit according to the manufacturer's instructions (Cayman Chemicals). Briefly, ethyl acetate-extracted samples were diluted to 1:50 in EIA buffer provided in the EIA kit, mixed with an equal volume of corticosterone AChE tracer and of corticosterone EIA antiserum on a 96-well plate, and incubated for $2 \mathrm{~h}$ at room temperature on an orbital shaker. Then, wells were emptied and rinsed five times with wash buffer. Ellman's Reagent in the kit was added to $200 \mu \mathrm{l}$ per well and incubated for $90 \mathrm{~min}$ at room temperature in the dark on a rotary shaker (35 $\mathrm{rpm})$. The reaction was measured at $405 \mathrm{~nm}$ using a spectrofluorometer (SpectraMax M5, Molecular Devices.

Drug administration. Mice were intraperitoneally injected with imipramine $(20 \mathrm{mg} / \mathrm{kg} / \mathrm{d})$, apocynin $(15 \mathrm{mg} / \mathrm{kg} / \mathrm{d})$, or vitamin C $(15 \mathrm{mg} /$ $\mathrm{kg} / \mathrm{d}) 1 \mathrm{~h}$ before the start of each $2 \mathrm{~h}$ restraint in the cotreatment paradigm, or each day from the next day after the last restraint in the posttreatment paradigm, for indicated periods. Imipramine (molecular mass, 280.4), apocynin (molecular mass, 166.2), and vitamin C (Lascorbic acid; molecular mass, 176.1) were purchased from SigmaAldrich. Apocynin was dissolved in dimethylsulfoxide (DMSO) and then diluted in saline. Other drugs were dissolved in saline. Each drug was finally diluted in $100 \mu \mathrm{l}$ of $0.9 \%$ saline and administered at the dose indicated.

Behavioral assessments. Mice were brought to the testing room $30 \mathrm{~min}$ before the start of each behavioral test and remained in the same room through the test. Behavioral tests were performed with a computerized video tracking system (SMART, Panlab). At all times, sound was masked with 60-65 dB white noise.

Sociability test. Sociability tests were performed either by following the procedure of Berton et al. (2006) with a minor modification or using the U-field test, a novel behavioral test developed in the present study. In the open-field type apparatus, similar to that described by Berton et al. (2006), each subject mouse was introduced into the open field (45 $\times$ $45 \times 40 \mathrm{~cm})$ containing an empty rectangular mesh cage $(15 \times 8 \times 17$ 
$\mathrm{cm}$ ) located at one end of the field for $5 \mathrm{~min}$ for habituation. The mouse was then placed back into its home cage for $1 \mathrm{~min}$. The subject mouse was tested for its trajectory in the same open field with a social target animal (an aged aggressive B6/SJL male mouse) in a mesh cage for $5 \mathrm{~min}$. The video tracking system was used to determine the time spent by the experimental mouse in the interaction zone (an 8-cm-wide corridor surrounding the target animal cage) and the corner zones $(18 \times 18 \mathrm{~cm})$ of the open field at the side opposite to the location of the target cage.

The U-field consisted of the two symmetrical rectangular fields attained by partitioning the open field $(45 \times 45 \times 40 \mathrm{~cm})$ with a wall to the central point, so that each field had closed and open squares, giving it a $U$ shape. A circular grid cage $(12 \mathrm{~cm}$ in diameter $\times 33 \mathrm{~cm}$ in height) was placed on each side of the closed square. The closed square containing a circular grid cage with a social target (see Fig. $6 E$, highlighted in green) is called the target zone, whereas the closed square that was unanimated (see Fig. 6E, highlighted in orange) is called the nontarget zone. Likewise, relevant fields (each including closed and open squares) were named target and nontarget fields, respectively. The open square in the target field and nontarget field was called, respectively, target transition zone and nontarget transition zone. We defined the target zone and target field as the social interaction zone and social field, respectively. In the U-field test, each mouse was introduced into the middle of each U-field. The subject mouse was tested for its trajectory in the U-field for 5 or 10 min. Normal B6 mice were used as a social target. Each target mouse served as a social target 3-4 times in total. Social target mice were prepared as subject mice were purchased. All animals including social targets were kept in pairs in normal plastic home cages except when they were located in the U-field.

Tail suspension test. Mice were suspended individually by their tails from a metal rod fixed $50 \mathrm{~cm}$ above the surface of a table in a test room. The tip of the tail was fixed using adhesive tape. The subject mouse was suspended by the tail for $6 \mathrm{~min}$ and the immobility time was counted for the last $5 \mathrm{~min}$.

Forced swim test. The forced swim test was performed as previously described (Kim and Han, 2006). Mice were placed in a Plexiglas cylinder (height, $27 \mathrm{~cm}$; diameter, $15 \mathrm{~cm}$ ) containing water at $24^{\circ} \mathrm{C}$ and at a depth of $14 \mathrm{~cm}$. Mice were individually placed in the cylinder for $15 \mathrm{~min}$ and returned to a home cage after drying quickly with a towel. On the following day, the subject mouse was placed in the cylinder for $6 \mathrm{~min}$. Animal's behavior during the last 5 min was scored as described previously (Kim and Han, 2006). Immobility time, which was defined as the summed time during which animals remained floating with all limbs motionless, was counted for the last $5 \mathrm{~min}$.

Measurement of lipid peroxidation. Lipid peroxidation was assessed by measuring malondialdehyde (MDA) levels using the Bioxytech MDA-586 kit (Oxis Research) as described previously (Im et al., 2006). Briefly, brain tissues, HT22 cells, or SH-SY5Y cells were homogenized in 4 volumes of ice-cold $20 \mathrm{~mm}$ PBS, pH 7.4, containing 5 mm butylated hydroxytoluene. Homogenates were centrifuged at $3000 \mathrm{~g}$ for $10 \mathrm{~min}$ at $4^{\circ} \mathrm{C}$, and the supernatant was used for each assay. For each reaction, $10 \mu \mathrm{lof}$ probucol and $640 \mu$ l of diluted R1 reagent (1:3 of methanol/N-methyl-2-phenylindole) were added and mixed with $150 \mu \mathrm{l}$ of $12 \mathrm{~N} \mathrm{HCl}$. Each reaction was incubated at $45^{\circ} \mathrm{C}$ for $60 \mathrm{~min}$ and centrifuged at $10,000 \mathrm{~g}$ for $10 \mathrm{~min}$. The supernatant was measured at $586 \mathrm{~nm}$. MDA data were normalized over the protein concentration and expressed as a percentage of the sham control value. Protein-bound MDA content was obtained by subtraction.
B

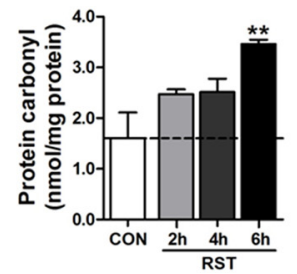

C

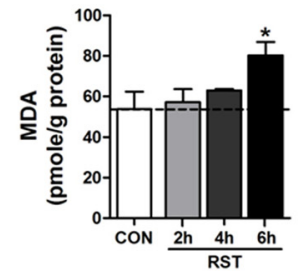

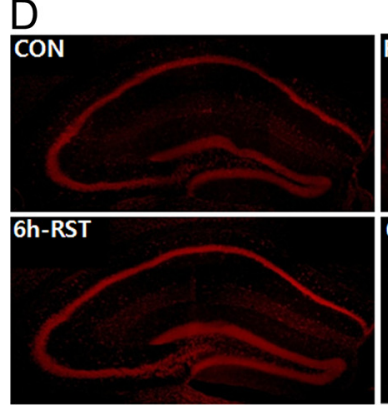
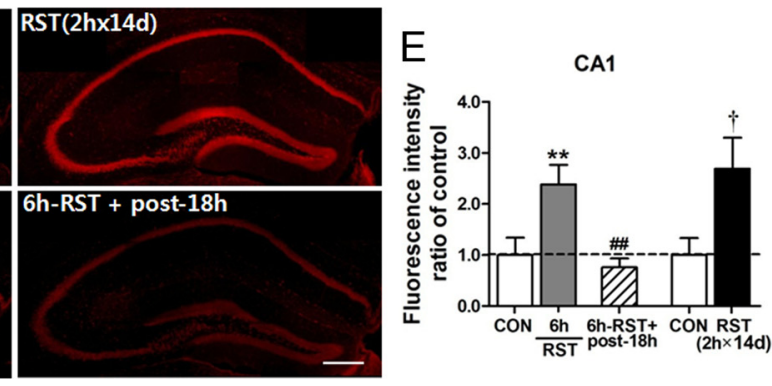

Figure 2. Stress increased GC and ROS levels in the brain. $\boldsymbol{A}$, Stress-dependent increase of GC in the brain tissue. GC levels were restraint. $\mathrm{GC}$ levels were also measured from the hippocampus immediately after $2 \mathrm{~h} \times 14 \mathrm{~d}$ restraint. Brains were prepared from increase of lipid peroxidation and protein carbonylation levels. Restraint was treated for 2,4 , or $6 \mathrm{~h}$ ( $n=6$ for each group). 0.01 for protein carbonylation levels]. D, E, DHE-reactive ROS levels in the hippocampus after $2 \mathrm{~h} \times 14 \mathrm{~d}$ restraint $[\mathrm{RST}(2 \mathrm{~h} \times$ Scale bar, $200 \mu \mathrm{m}$. Data are presented as the means \pm SEM. * and **, differences from the control; \# and \#\#, differences from the $6 \mathrm{~h} \times 1 \mathrm{~d} \mathrm{RST}$ group; $†$ and $+\dagger$, differences from the control of the RST $(2 \mathrm{~h} \times 14 \mathrm{~d})$ group, at $p<0.05$ and $p<0.01$, respectively.

Cell culture and drug treatment. SH-SY5Y human neuroblastoma cells and HT22 mouse hippocampus cells were cultured by following the standard method described previously (Choi et al., 2006; Seo et al., 2011). Briefly, SH-SY5Y or HT22 cells were cultured in DMEM (Invitrogen-BRL) supplemented with $10 \%$ heat-inactivated FBS (Gibco), penicillin $(20 \mathrm{U} / \mathrm{ml})$, and streptomycin $(20 \mathrm{mg} / \mathrm{ml})$ at $37^{\circ} \mathrm{C}$ in a humidified incubator gassed with $95 \%$ air and $5 \% \mathrm{CO}_{2}$. Cells at $70-80 \%$ confluence were used for all experiments. $\mathrm{H}_{2} \mathrm{O}_{2}, \mathrm{Mn}(\mathrm{III})$ tetrakis(4-benzoic acid)porphyrin chloride (MnTBAP) and vitamin $\mathrm{C}$ were dissolved in PBS. GC (cortisol or corticosterone), apocynin, and RU486 (mifepristone) were dissolved in DMSO and then diluted in PBS. Cells were incubated with GC and $\mathrm{H}_{2} \mathrm{O}_{2}$ in serum-free DMEM.

Detection of superoxide levels in vitro and in vivo. Superoxide levels were measured using dihydroethidium (DHE), a cell membranepermeable superoxide-sensitive fluorescent dye (Invitrogen), as described previously (Im et al., 2006). Briefly, SH-SY5Y or HT22 cells were incubated for $10 \mathrm{~min}$ at $37^{\circ} \mathrm{C}$ in HBSS buffer, $\mathrm{pH}, 7.4$, containing $10 \mu \mathrm{M}$ DHE in 96-well plates. Cultures were washed twice with HBSS. Fluorescence levels were measured at $540 \mathrm{~nm}$ excitation and $590 \mathrm{~nm}$ emission using a spectrofluorometer (SpectraMax M5, Molecular Devices). The procedure was repeated three times.

Superoxide levels in brain sections were also measured using DHE by following the procedure described previously (Banes et al., 2005), with a modification. Briefly, hippocampal sections were incubated with $1 \mu \mathrm{M}$ DHE in $1 \times$ PBS in wells of a 24-well plate at room temperature for $5 \mathrm{~min}$ with mild shaking on a rotary shaker, while protecting the incubating sections from light using aluminum foil. Sections were washed three times with $1 \times$ PBS. Fluorescence images were analyzed using a microscope (BX 51, Olympus) equipped with a DP71 camera and DP-manager and DP-Controller software (Olympus). Expression levels were quantified using the TOMORO ScopeEye 3.6 program (Techsan Community, Seoul, Korea). 
Immunohistochemistry. Brains were perfused with $4 \%$ paraformaldehyde via a transcardiac method and postfixed in the same solution overnight at $4^{\circ} \mathrm{C}$. The brains were coronally cut into $40 \mu \mathrm{m}$-thick sections with a vibratome (VT 1000S, Leica). Free-floating sections were incubated for $30 \mathrm{~min}$ in $0.3 \% \mathrm{H}_{2} \mathrm{O}_{2}$ in $0.1 \mathrm{M}$ PBS to quench peroxidase activity. Sections were washed three times with $0.1 \mathrm{M}$ PBS containing $0.1 \%$ Triton X-100 (PBST), pH 7.4, for 10 min each time and permeabilized with PBST in the presence of $2 \%$ normal goat serum, $2 \%$ normal horse serum, and 2\% BSA for $1 \mathrm{~h}$. Brain sections were then reacted with a 1:100 dilution of anti-p47phox antibody (Santa Cruz Biotechnology) at $4^{\circ} \mathrm{C}$ overnight. The sections were washed with PBST, reacted with biotinylated secondary antibody diluted 1:200 in PBST, and visualized using an $\mathrm{ABC}$ Elite kit (Vector Laboratories). Stained images were analyzed using an Olympus BX 51 microscope equipped with a DP71 camera and using a TOMORO ScopeEye 3.6 program, as described above. Expression levels of $\mathrm{p} 47 \mathrm{phox}$ in the pyramidal layer were quantified after normalizing the cell body staining to the stratum radiatum layer.

Conventional RT-PCR and real-time PCR. RNA preparation, conventional RT-PCR, and real-time PCR were performed as described previously (Ha et al., 2008; Seo et al., 2011). Total RNA was purified from brain tissue or cultured cells using TRI Reagent (Invitrogen), and treated with DNase I to avoid genomic contamination. First-strand cDNA was synthesized from $2 \mu \mathrm{g}$ of total RNA using a RT-PCR kit (Promega) in a total volume of $20 \mu \mathrm{l}$.

Real-time PCR was performed with a mix of $10 \mu \mathrm{l}$ of $2 \times$ iQ SYBR Green supermix (Bio-Rad Laboratories), $1 \mu \mathrm{l}$ each of $5 \mathrm{pmol} / \mu \mathrm{l}$ forward and reverse primers, and $4 \mu \mathrm{l}$ of cDNA (1:8 dilution of the convert) in a volume of $20 \mu \mathrm{l}$ using the CFX 96 Real-Time PCR System Detector (Bio-Rad Laboratories). The procedure comprised $5 \mathrm{~min}$ at $95^{\circ} \mathrm{C}$, followed by 40 cycles of $20 \mathrm{~s}$ at $95^{\circ} \mathrm{C}, 20 \mathrm{~s}$ at $56^{\circ} \mathrm{C}$, and $20 \mathrm{~s}$ at $72^{\circ} \mathrm{C}$. Real-time PCR analyses were performed using the primer sets of $5^{\prime}$-ACCGGCTA TTTCCCATCC and 5' -TGGATGCTCTGTGCGTTG-3' for p47phox, and $5^{\prime}$-CATGAAGCACACCATCCAGTCC- 3 ' and $5^{\prime}$-GATTTCTCTTCC TGTTTGTCCATCTG-3' for p67phox. GAPDH and $\beta$-actin were used as references with the primers $5^{\prime}$-AGAAGGTGGTGAAGCAGGCA 'TC-3' and 5'-CGAAGGTGGAAGAGTGGGAGTTG-3' for GAPDH, and $5^{\prime}$-ATCGTGCGTGACATCAAAGAGAAG- ${ }^{\prime}$ and $5^{\prime}$-TGCCACAG GATTCCATACCCAAG- $3^{\prime}$ for $\beta$-actin. Transcription levels were also examined by conventional RT-PCR using the following primer sets: $\mathrm{p} 47-$ phox, 5' -CAGCCAGCACTATGTGTACA-3' and 5' -GAACTCGTAGAT CTCGGTGAA-3'; and p67-phox, 5'-GGGAACCAGCTGATAGAC TA- ${ }^{\prime}$ and $5^{\prime}$-TCCATTCCTCYTTCTTGGCA- ${ }^{\prime}$. Validation of these primer sets has been described previously (Tammariello et al., 2000). The primer set for $\beta$-actin was the same as above.

Use of small interfering RNA-p47phox. SH-SY5Y cells were seeded $24 \mathrm{~h}$ before transfection and allowed to reach $70 \%$ confluence on the day of transfection (Seo et al., 2011). Small interfering RNA (siRNA)-p47phox was obtained from Bioneer Technology (\#1390462 duplex). The siRNAp47phox sequences of the sense and antisense strands were $5^{\prime}$-CUAUUU CCCAUCCAUGUAU-3' and 5'-AUACAUGGAUGGGAAAUAG-3', respectively. The nontargeting siRNA controls [6-carboxyfluorescein fluorophore-labeled oligonucleotide siGLO Green (\#D-001630-0105) and nontargeting siRNA control (\#D-001210-0205)] were purchased from Dharmacon. Cells were transfected with $100 \mathrm{~nm}$ siRNA diluted in DMEM using Lipofectamine reagent (Invitrogen). Knockdown of p47phox was confirmed by real-time PCR and immunocytochemistry using anti-p47phox antibody.

Lentiviral vector production and concentration. Recombinant lentivirus was produced as described previously (Min et al., 2010). Lenti-empty vector shRNA control (mouse pGIPZ lentiviral shRNAmir; \#RMM4431) and Lenti shRNA-p47phox (\#RMM4431-98723759, oligo \#V2LMM_3405) were purchased from Open Biosystems. Briefly, three plasmids, including a transfer vector, an envelope glycoprotein expression lentiviral vector (Macrogen), and a packaging vector, were cotransfected into 293T cells at a 1:1:1 molar ratio with Lipofectamine Plus (Invitrogen). The culture supernatant containing viral vector particles was harvested $48 \mathrm{~h}$ after transfection, filtered with a $0.45 \mu \mathrm{m}$ membrane (Nalgene), and stored at $-70^{\circ} \mathrm{C}$. Lentiviral vector expression levels were analyzed by RT-RCR, Western blot, and ELISA. p24 ELISA, performed after infection of HeLa cells, yielded a titer of $\sim 10^{6}-10^{7}$
A
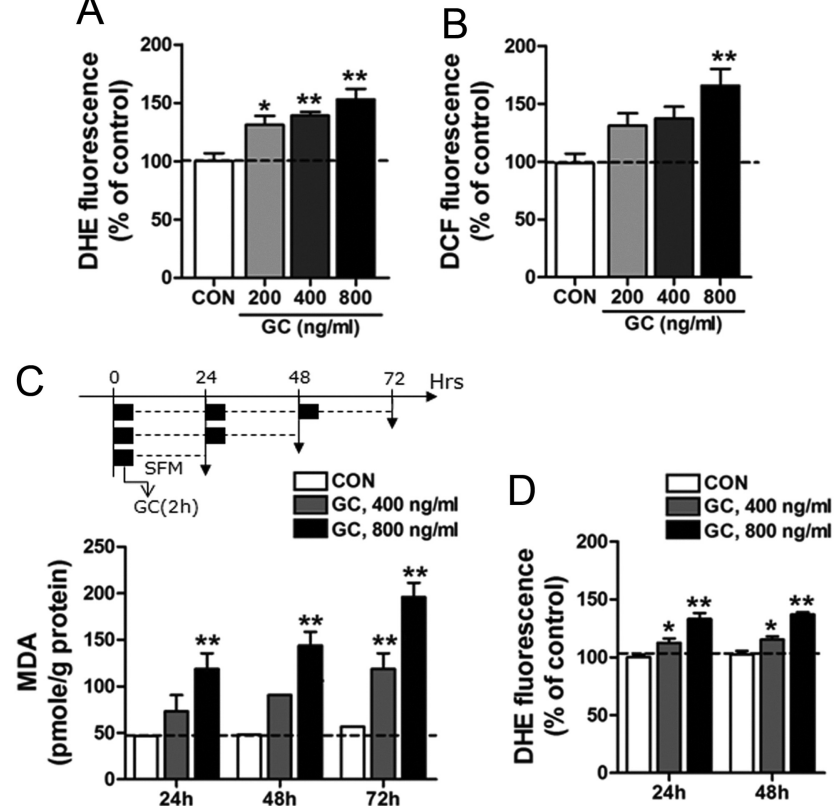

Figure 3. GC treatment increased superoxide and ROS levels in cultured neuronal cell lines $\boldsymbol{A}, \boldsymbol{B}$, Treatment of HT22 cells with GC accumulated superoxide $(\boldsymbol{A})$ and dichlorofluorescein (DCF)-reactive ROS levels $(\boldsymbol{B})$. HT22 cells were treated with GC at indicated doses for $24 \mathrm{~h}$. Superoxide and ROS levels were measured by staining with DHE and DCF, respectively. CON, control cells; GC, cells treated with GC. One-way ANOVA and Newman-Keuls post hoc test; significant effects of $\mathrm{GC}$ on superoxide levels $\left[F_{(3,12)}=10.03, p<0.01\right]$ and ROS levels $\left[F_{(3,27)}=5.637, p<0.01\right]$. C, MDA levels after treatment with GC in SH-SY5Y cells. Cells were treated with GC (400 or $800 \mathrm{ng} / \mathrm{ml}$ ) for $2 \mathrm{~h}$ (black box) and, after washing, were cultured in serum-free medium (SFM) for $22 \mathrm{~h}$ (broken line). This procedure was repeated for $1-3 \mathrm{~d}$. Data were expressed as the percentage of the $24 \mathrm{~h}$ control. Two-way ANOVA and Bonferroni post hoc test; significant effect of GC doses $\left[F_{(2,45)}=54.51, p<0.0001\right]$ and time $\left[F_{(2,45)}=10.49, p<\right.$ $0.001]$, and no interaction between $G C$ dose and time $\left[F_{(4,45)}=1.993, p=0.1118\right]$. D, Treatment with GC in SH-SY5Y cells generated superoxide. Cells treated with GC (400 or $800 \mathrm{ng} / \mathrm{ml}$ ) for $2 \mathrm{~h}$ daily for 24 or $48 \mathrm{~h}$. Superoxide levels were measured by staining with DHE. Two-way ANOVA and Bonferroni post hoc test; significant effect of $G C$ doses $\left[F_{(2,30)}=52.88, p<0.0001\right]$, no effect of time $\left[F_{(1,30)}=1.365, p=0.2519\right]$, and no interaction between $\mathrm{GC}$ dose and time $\left[F_{(2,30)}=0.02626, p=0.9741\right]$. Data are presented as the means $\pm \operatorname{SEM}(n=4-8) .{ }^{*}$ and ${ }^{* *}$, differences from the control at $p<0.05$ and $p<0.01$, respectively.

transduction units (TU) per milliliter. Green fluorescent protein (GFP) expression was confirmed after transfection in HeLa cells or A594 cells. Virus concentration was made by filtration with Centricon (Millipore). The viral particles were further concentrated by ultracentrifugation at $80,000 \times \mathrm{g}$ for $2 \mathrm{~h}$. This concentration procedure was repeated twice. The final titer of $\sim 10^{10}-10^{12}$ TU per milliliter was obtained and used in experiments.

Stereotaxic injection of lentiviral-shRNA. Male C57BL/6 mice (22-24 g) were anesthetized by intraperitoneal injection of 3.5:1 mixture of ketamine $(50 \mathrm{mg} / \mathrm{ml})$ and xylazine hydrochloride $(23.3 \mathrm{mg} / \mathrm{ml})$ at a dose of $1.0 \mu \mathrm{l} / \mathrm{g}$ body weight, and placed on a stereotaxic apparatus (Stoelting) as described previously (Kim et al., 2008). Lenti shRNA in a volume of $3 \mu \mathrm{l}$ was injected into each dentate gyrus of the hippocampus at the speed of $0.5 \mu \mathrm{l} / \mathrm{min}$ (stereotaxic coordinates in millimeters with reference to the bregma: anteroposterior, -2.4 ; mediolateral, \pm 2.0 ; dorsoventral, -2.1 ) using a $28 \mathrm{G}$ needle. After $5 \mathrm{~min}$, the needle was removed with three intermediate steps for 3 min to minimize backflow, and mice were kept on a warm pad until awakened. Surgically manipulated mice awakening from anesthesia were returned to their home cages until use. After $14 \mathrm{~d}$ of injection, depression-like behavioral tests were performed.

Statistical analyses. Two-sample comparisons were performed using the Student's $t$ test, while multiple comparisons were made using oneway or two-way ANOVA followed by post hoc tests to compare selected pairs of data. PRISM software 5.0 (GraphPad Software) was used to 
perform statistical analyses. All data are presented as the mean \pm SEM, and statistical differences were accepted at the $5 \%$ level.

\section{Results}

Repeated $2 \mathrm{~h} \times 14 \mathrm{~d}$ restraint induced long-lasting changes in depression-related behavior

Mice restrained for $2 \mathrm{~h}$ daily for $14 \mathrm{~d}$ (2 $\mathrm{h} \times 14 \mathrm{~d}$ stress) showed depressive behavior in the forced swim test (Kim and Han, 2006). In the present study, lasting effect of the $2 \mathrm{~h} \times 14 \mathrm{~d}$ stress on depressive behavior was reevaluated using the social interaction test, a behavioral test that may hold a neurobiological relevancy to human depression (Nestler and Hyman, 2010). On poststress day 15 (Fig. 1A), mice treated with the $2 \mathrm{~h} \times 14 \mathrm{~d}$ stress spent less time in the interaction zone with an unfamiliar mouse and more time in the corner zones, compared with control mice, thus displaying significantly aversive responses to an unfamiliar mouse. Poststress treatment with imipramine, an antidepressant used in clinics, reversed the poor sociability (Fig. $1 B$ ). On poststress days 28-29, stressed mice showed increased immobility in the tail suspension test (TST) and forced swim test (FST), and such depressive behavior was surprisingly detected on poststress days 89-90. Antidepressive effect of imipramine, when treated in poststress days, was evident on poststress day 28 , but its effect, when terminated on poststress day 21, was diminished on poststress days 89-90 (Fig. 1C,D).

\section{Repeated restraint increases lipid peroxidation levels in the brain in a stress-repetition-dependent manner}

We examined stress-induced ROS accumulation profiles in the brain by measuring lipid peroxidation levels. Repeated restraints progressively increased the levels of lipid peroxidation, and lipid peroxidation level was highest after the fourteenth restraint (Fig. $1 E, F)$. In the absence of further stress, the ROS burst returned close to the basal level in a day (Fig. $1 E$ ). However, the stressed mice showed an enhanced ROS surge to restress given on poststress days 14-21 (Fig. 1 E). Stress-induced ROS accumulation in the hippocampus was $35.8 \%$ higher than in the prefrontal cortex, suggesting that the hippocampus is more sensitive to ROS accumulation than the prefrontal cortex (Fig. $1 F$ ).

Restraint increased GC levels in blood rapidly, and the GC level induced by $2 \mathrm{~h}$ restraint dropped in $2 \mathrm{~h}$ near to the baseline level (Kim and Han, 2006, 2009). We wanted to know whether restraint increased GC levels in the brain tissue. We found that GC levels measured from the hippocampus immediately after $2 \mathrm{~h}$ or $6 \mathrm{~h}$ restraint increased in a stress-length-dependent manner, but the GC level increased by $6 \mathrm{~h}$ restraint in the hippocampus was reduced to the control level by the following day (Fig. 2 A). The GC level measured immediately after $2 \mathrm{~h} \times 14 \mathrm{~d}$ restraint also increased, but the level was not higher than that induced by $2 \mathrm{~h}$ restraint (Fig. $2 \mathrm{~A}$ ). Restraint increased lipid peroxidation levels and protein carbonylation levels in a stress-length-dependent manner (Fig.
B
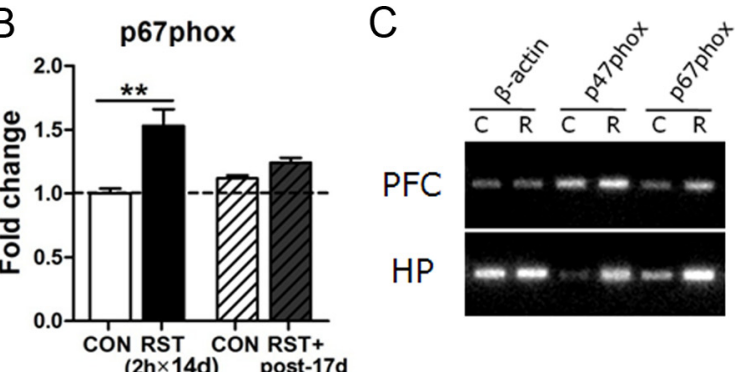

$(2 h \times 14 d) \quad$ post-17d

E CA1

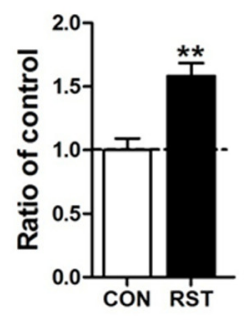

Figure 4. Repeated stress increased the expression of p47phox and p67phox in the brain. $A, B$, Real-time $P C R$ data showing , Exotomicrographs showing the expression of p47phox in the CA1 pyramidal cell layers of the hippocampus of the Scale bar, $100 \mu \mathrm{m}$. Student's t test $(p<0.01)$. Data are presented as the means $\pm \operatorname{SEM}(n=6-8) .{ }^{*}$ and ${ }^{* *}$, differences from the control at $p<0.05$ and $p<0.01$, respectively.

$2 B, C)$. The $2 \mathrm{~h} \times 14 \mathrm{~d}$ restraint increased DHE-reactive superoxide in the hippocampus of brain sections (Fig. $2 D, E$ ). Collectively, these data suggest that stress increased ROS levels in correlation with GC levels in the brain tissue.

Next, we examined the mechanism regulating GC-induced ROS production in HT22 mouse hippocampal cells and $\mathrm{SH}$ SY5Y human neuroblastoma cells. Treatment with GC in HT22 cells produced reactive superoxide and dichlorofluoresceinreactive ROS in a GC-dose-dependent manner (Fig. 3 A, B). Consistently, in SH-SY5Y cells, treatment with GC ( 400 or $800 \mathrm{ng} / \mathrm{ml}$ ) for $2 \mathrm{~h}$ daily for $1-3 \mathrm{~d}$ increased lipid peroxidation levels (Fig. $3 \mathrm{C}$ ) and superoxide levels (Fig. 3D).

\section{NADPH oxidase mediates stress-induced and GC-induced ROS production in vivo and in vitro}

Next, we searched for cellular factors regulating the ROS surge in the stressed brain. Among many ROS-regulating genes examined by quantitative real-time PCR, the NADPH oxidase subunits p47phox and p67phox were noted because their expressions increased in a stress-dependent manner (Fig. 4A,B). NADPH oxidase is a major player in superoxide generation in many cell types (Serrano et al., 2003; Lambeth, 2004; Tejada-Simon et al., 2005; Bedard and Krause, 2007). Independent work with RT-PCR showed that expressions of $\mathrm{p} 47$ phox and p67phox in the prefrontal cortex and hippocampus increased after $2 \mathrm{~h} \times 14 \mathrm{~d}$ stress (Fig. $4 C)$. Immunohistological study also confirmed an increase of p47phox expression in the brain, including the cerebral cortex 

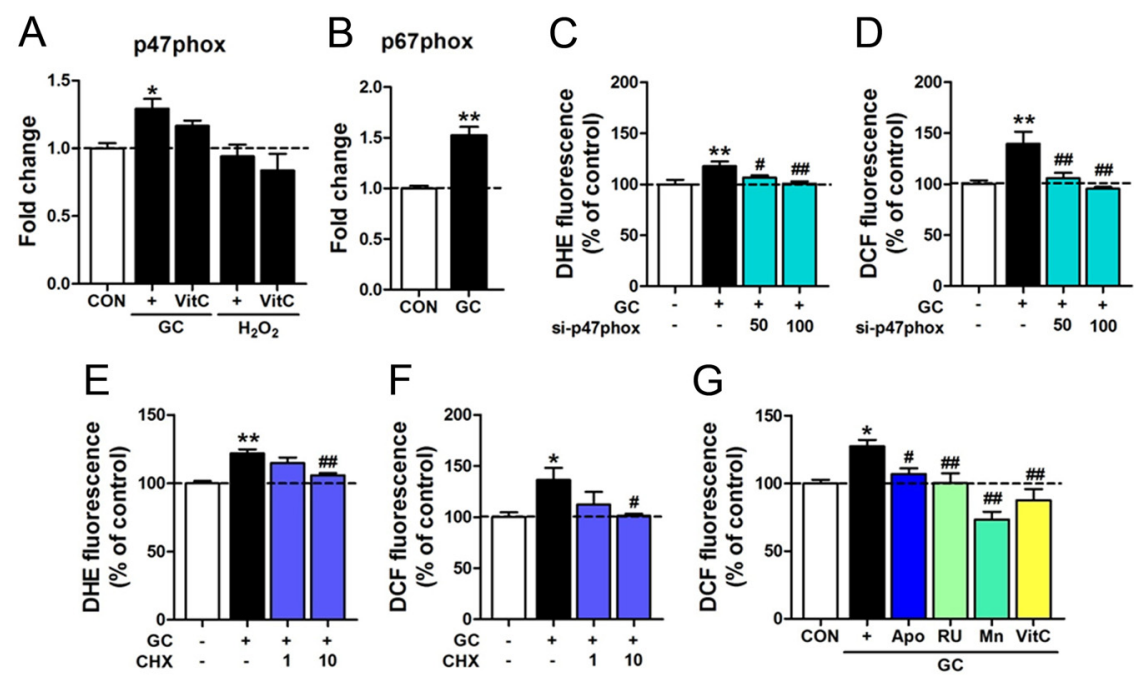

Figure 5. NADPH oxidase mediated GC-induced ROS production in neuronal cells. $\boldsymbol{A}, \boldsymbol{B}$, Real-time $\mathrm{PCR}$ data showing expression levels of p47phox $(\boldsymbol{A})$ and p67phox $(\boldsymbol{B})$ in SH-SY5Y cells treated with $\mathrm{GC}(400 \mathrm{ng} / \mathrm{ml})$ or $\mathrm{H}_{2} \mathrm{O}_{2}(200 \mu \mathrm{m})$ for $24 \mathrm{~h}$ in the presence or absence of vitamin C (VitC, $200 \mu \mathrm{M})$. One-way ANOVA and Newman-Keuls post hoc test; significance of effect of GC and its partial suppression by vitamin $C\left[F_{(4,25)}=5.333, p<0.01\right]$, but no effect of $\mathrm{H}_{2} \mathrm{O}_{2}$. Student's $t$ test for p67phox. C, D, siRNA-p47phox transfection suppressed GC-induced ROS levels. After $24 \mathrm{~h}$ of transfection with siRNA-p 47phox ( 50 or $100 \mathrm{~nm}$ ), GC ( $400 \mathrm{ng} / \mathrm{ml}$ ) was treated for 48h, and ROS generation was evaluated using DHE (C) or dichlorofluorescein (DCF) (D). One-way ANOVA and NewmanKeuls post hoc test $\left[F_{(3,20)}=5.449, p<0.01\right.$ for superoxide levels; $F_{(3,20)}=8.446, p<0.001$ for ROS levels]. $\boldsymbol{E}, \boldsymbol{F}, \mathrm{GC}$-induced superoxide $(\boldsymbol{E})$ and ROS $(\boldsymbol{F})$ accumulation was blocked by cyclohexamide. One-way ANOVA and Newman-Keuls post hoc test $\left[F_{(3,20)}=12.61, p<0.0001\right.$ for superoxide levels; $F_{(3,20)}=3.511, p<0.05$ for ROS levels]. G, GC-enhanced ROS levels were blocked by apocynin (Apo, $500 \mu \mathrm{M})$, RU486 (RU, $20 \mu \mathrm{M})$, MnTBAP (Mn, $100 \mu \mathrm{m})$, or vitamin C (VitC, $200 \mu \mathrm{m})$. SH-SY5Y cells were treated with GC ( $400 \mathrm{ng} / \mathrm{ml})$ for $48 \mathrm{~h}$, and ROS levels were evaluated with DCF. One-way ANOVA and Newman-Keuls post hoc test $\left[F_{(5,24)}=10.04, p<0.0001\right]$. Data are presented as the means \pm SEM $(n=6-12) .{ }^{*}$ and ${ }^{* *}$, differences from the control; \# and $\#$ \#, differences from $\mathrm{GC}$-treated group, at $p<0.05$ and $p<0.01$, respectively.

and hippocampus. In the hippocampus, p47phox expression was detected in the pyramidal cell layer (Fig. $4 D, E$ ).

In SH-SY5Y cells, treatment with GC, but not $\mathrm{H}_{2} \mathrm{O}_{2}$, increased the expression of $\mathrm{p} 47 \mathrm{phox}$. Treatment with GC also increased the expression of p67phox (Fig. 5A,B). Transfection of siRNAp47phox blocked GC-induced ROS and superoxide generation (Fig. $5 C, D$ ). Consistent with these data, GC-induced accumulation of superoxide and ROS was blocked by cyclohexamide (Fig. $5 E, F)$. GC-induced ROS production in SH-SY5Y cells was also inhibited by the GC receptor antagonist RU486, the SOD mimetic MnTBAP, or by vitamin C. Moreover, GC-induced ROS production was blocked by the NADPH oxidase inhibitor, apocynin (Fig. $5 G$ ), supporting the pivotal role of NADPH oxidase in GC-induced ROS production.

Next, we examined whether pharmacological inhibition of NADPH oxidase was sufficient to modulate ROS production in an animal level. Repeated restraint progressively increased lipid peroxidation levels, whereas cotreatment with apocynin $(15 \mathrm{mg} / \mathrm{kg})$ blocked stress-induced oxidative stress (Fig. 6A,B). Consistent with these data, mice treated with apocynin showed no sign of depressive behavior in TST and FST, as did mice treated with imipramine (Fig. $6 C, D)$. Administration of apocynin in the stressed mice in the poststress period also reversed the depressive behavior in the U-field test, a novel sociability test developed and introduced in the present study for the first time (Fig. 6E,F). The antidepressive effect of apocynin administered in the poststress period was comparable to that of imipramine (Fig. 6C-H).

Molecular or genetic targeting of $\mathrm{p} 47 \mathrm{phox}$ is sufficient to suppress depression-like behavior

The role of NADPH oxidase in stress responses was further examined using heterozygous p47phox knock-out mice $\left(p 47 p h o x^{+/-}\right)$. Upon treatment with $2 \mathrm{~h}$ $\times 14 \mathrm{~d}$ restraint, the expression of p47phox was enhanced in p47phox ${ }^{+/-}$ mice, but the induction level was low compared with the wild-type control. The wild-type mice treated with the $2 \mathrm{~h} \times 14 \mathrm{~d}$ restraint showed a pronounced expression of p47phox to restress $(2 \mathrm{~h} \times 3 \mathrm{~d}$ restraint) evoked on poststress days $21-$ 23 , whereas $p 47 p h o x^{+/-}$mice treated with the $2 \mathrm{~h} \times 14 \mathrm{~d}$ stress did not show such augmented responses (Fig. $7 A, B$ ). The expression of p67phox in p47phox ${ }^{+/-}$mice was increased by the $2 \mathrm{~h}$ $\times 14 \mathrm{~d}$ stress and $2 \mathrm{~h} \times 3 \mathrm{~d}$ restress, as in wild-type mice (Fig. $7 C$ ). Consistent with this molecular data, wild-type littermates treated with the $2 \mathrm{~h} \times 14 \mathrm{~d}$ restraint showed depression-like behavior in TST and FST, whereas $p 47 p h o x^{+/-}$mice did not (Fig. $7 D, E)$.

As a complementary study to the genetic approach, Lenti-shRNA-p47phox or Lenti-GFP control was infused into the hippocampus of normal mice (Fig. $7 F$ ). After the $2 \mathrm{~h} \times 14 \mathrm{~d}$ restraint, the LentiGFP control group displayed typical depression-like behavior, whereas the Lenti shRNA-p47phox group showed resiliency to depression (Fig. 7G,H).

When the $2 \mathrm{~h} \times 3 \mathrm{~d}$ restraint of restress was given (Fig. $7 F$ ), the expressions of p47phox and p67phox in the Lenti-GFP control were upregulated, whereas the expression of p47phox, but not p67phox, in the Lenti-shRNA-p47phox group remained low (Fig. $7 I, J$ ).

\section{Discussion}

\section{NADPH oxidase mediates stress-induced ROS buildup in the brain}

A salient feature in chronic stress response is the accumulation of oxidative stress in the brain (Fontella et al., 2005; Pérez-Nievas et al., 2007; Zafir and Banu, 2009). The results of the present study indicate that NADPH oxidase is a central player in stress-induced production of oxidative stress. Supporting this notion is the finding that the key components of NADPH oxidase complex, p47phox and p67phox, increased following stress (Fig. 4A,B), in parallel with the enhanced levels of the stress-induced ROS burst (Fig. 1 E). NADPH oxidase generates superoxide (Halliwell, 2006; Bedard and Krause, 2007; Brown and Griendling, 2009). Because superoxide can form its intermediate toxic product hydroxyl radical or perixonitrite in reaction with nitric oxide, superoxide and its reactants need to be tightly controlled by SODs (Miao and St. Clair, 2009; Buettner, 2011). NADPH oxidase is a major source of ROS production in various cell types (Lambeth, 2004; Bedard and Krause, 2007). In SH-SY5Y cells and HT22 cells, GC treatment generated superoxide, and GC-induced superoxide was blocked by p47phox-siRNA (Fig. 5C,D). Consistently, administration of apocynin in mice exposed to the $2 \mathrm{~h} \times 14 \mathrm{~d}$ stress completely suppressed stress-induced ROS burst in the brain (Fig. 6A,B). These results support the view that NADPH oxidase mediates stress-induced ROS accumulation in the brain. 


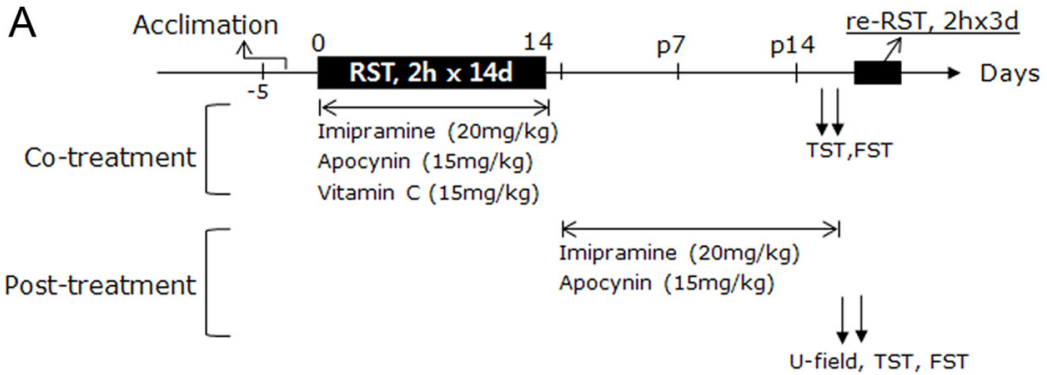

$\mathrm{B}$

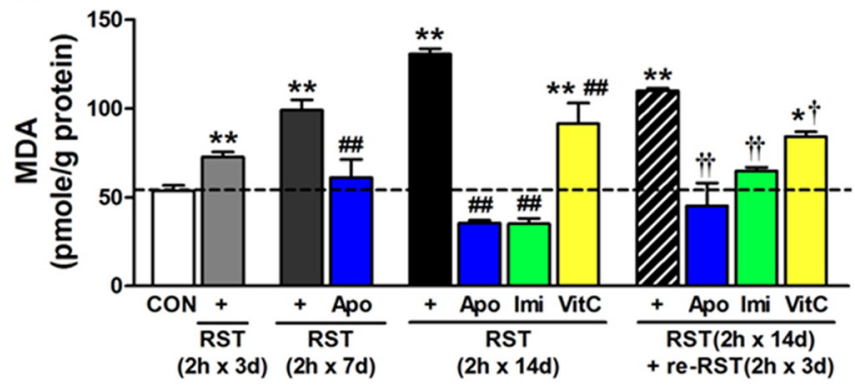

E

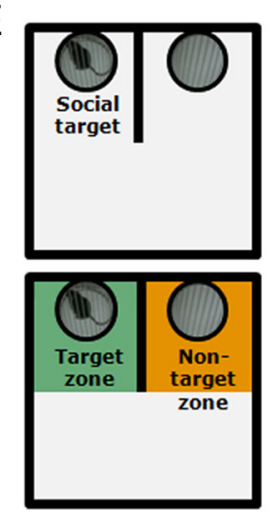

$F$

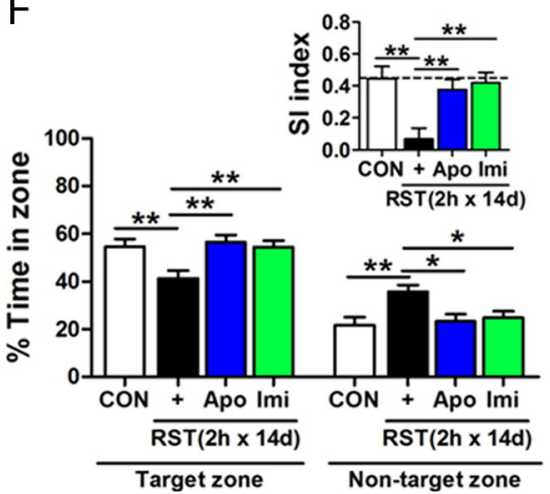

C

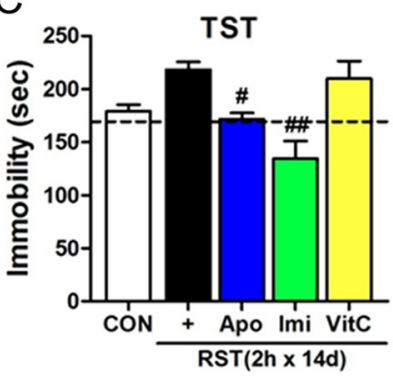

G

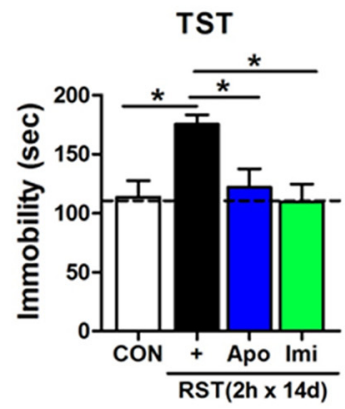

$\mathrm{D}$

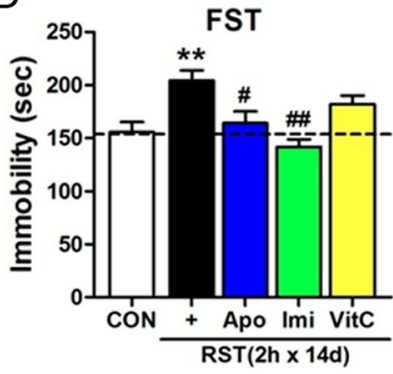

$\mathrm{H}$

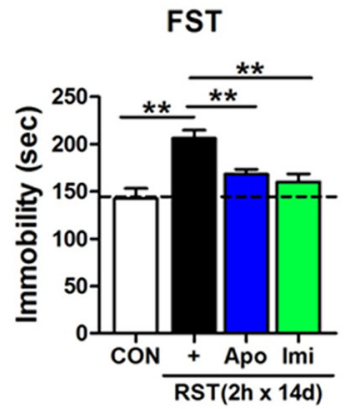

Figure 6. Pharmacological inhibition of NADPH oxidase blocked depressive behavior. $A$, Experimental design for treatment with apocynin and following behavioral tests. Drugs were treated during the stress period (cotreatment) or in the poststress period (post-treatment). Restress was given with $2 \mathrm{~h} \times 3 \mathrm{~d}$ restraint at the indicated time point. $\boldsymbol{B}$, MDA levels in the hippocampus after treatment with $2 \mathrm{~h}$ restraint for 3, 7, or $14 \mathrm{~d}$, together with imipramine (Imi; $20 \mathrm{mg} / \mathrm{kg}$ ), apocynin (Apo; $15 \mathrm{mg} / \mathrm{kg})$, or vitamin C (VitC, $15 \mathrm{mg} / \mathrm{kg})$. Restress ( $2 \mathrm{~h} \times 3 \mathrm{~d}$ restraint) was given from poststress day 17 ( $n=5-9)$. One-way ANOVA and Newman-Keuls post hoc test; a significant effect of restraint $\left[F_{(4,28)}=74.63, p<0.0001\right]$, significant effects of imipramine and apocynin in $2 \mathrm{~h}$ $\times 7$ d group $\left[F_{(2,14)}=14.91, p<0.001\right]$, in $2 \mathrm{~h} \times 14 \mathrm{~d}$ group $\left[F_{(4,27)}=58.28, p<0.0001\right]$, and in re-RST group $\left[F_{(4,26)}=14.36, p<0.0001\right]$. C, D, Behavioral performance of cotreated groups in TST $(\boldsymbol{C})$ and FST $(\boldsymbol{D})(n=5-10)$. One-way ANOVA and Newman-Keuls post hoc test $\left[F_{(4,36)}=8.986, p<0.0001\right.$ for TST; $F_{(4,23)}=6.803, p<0.001$ for FST]. $\boldsymbol{E}$, The U-field with a social target (top). Target and nontarget zones are indicated in green and orange (bottom). $\boldsymbol{F}$, Percentage time spent in target and nontarget zones for the first 5 min period in the $U$-field test. The fraction of the time spent in the target zone minus the fraction of the time in the nontarget zone is taken as the social interaction (SI) index (right top, inset) ( $n=8-11$ ). 0ne-way ANOVA and Newman-Keuls post hoc test $\left[F_{(3,32)}=5.606, p<0.01\right.$ for target zone; $F_{(3,32)}=5.197, p<0.01$ for nontarget zone; and $F_{(3,32)}=7.225, p<0.001$ for the social index $]$. $\boldsymbol{G}, \boldsymbol{H}$, Behavioral performance of post-treated groups in TST (G) and FST $(\boldsymbol{H})(n=5-8)$. One-way ANOVA and Newman-Keuls post hoc test $\left[F_{(3,22)}=3.562, p<0.05\right.$ for TST; $F_{(3,22)}=8.874, p<0.001$ for FST]. Data are presented as the means \pm SEM. * and ${ }^{* *}$, differences from the control or between indicated group; \# and \#\#, difference from respective RST control, $†$ and $\dagger \dagger$, difference from re-RST ( $\left.2 \mathrm{~h} \times 3 \mathrm{~d}\right)$ control, at $p<0.05$ and $p<$ 0.01 , respectively.

\section{NADPH oxidase acts as a depression signature}

Treatment with apocynin during the stress period not only suppressed ROS production, but also blocked depression-like behavior. The antidepressant effect of apocynin was comparable to that of imipramine in several behavioral tests, whereas vitamin C suppressed GC-induced ROS in vitro, but its effect on behavior was negligible (Fig. 6C,D). Consistent with the pharmacological data, molecular genetic evidence supports the premise that NADPH oxidase has a critical role in promoting and maintaining depressive behavior (Fig. 7). These results support the idea that stressstimulated NADPH oxidase is the primary player mediating depressive behavior, and that NADPH oxidase may be a therapeutic target in controlling stress-induced depression. Recently, it was reported that rats exposed to social isolation for 7 weeks from weaning had enhanced expression of NOX2, p47phox, and p67phox in the brain, and enhanced expression of NADPH oxidase subunits was correlated with an impairment in the novel object recognition test and enhanced locomotion in the open field test (Schiavone et al., 2009), suggesting that stress-induced upregulation of NADPH oxidase activity may also affect cognitive functions.

Given that the $2 \mathrm{~h} \times 14 \mathrm{~d}$ stress produced strong depressive behavior that may last for $>3$ months (Fig. 1), stress effects accumulated during the stress period appears to be solidified and implemented into a long-lasting form (the "depression signature"). Persistently upregulated expression of NADPH oxidase meets the criteria of the depression signature. Moreover, it appears that NADPH oxidase as a depression signature becomes 


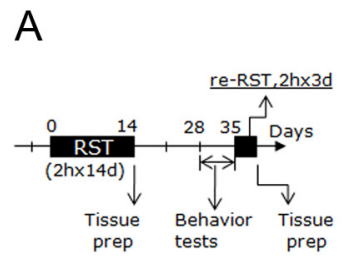

$\mathrm{F}$
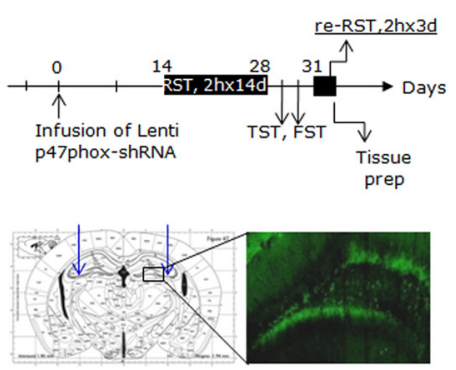
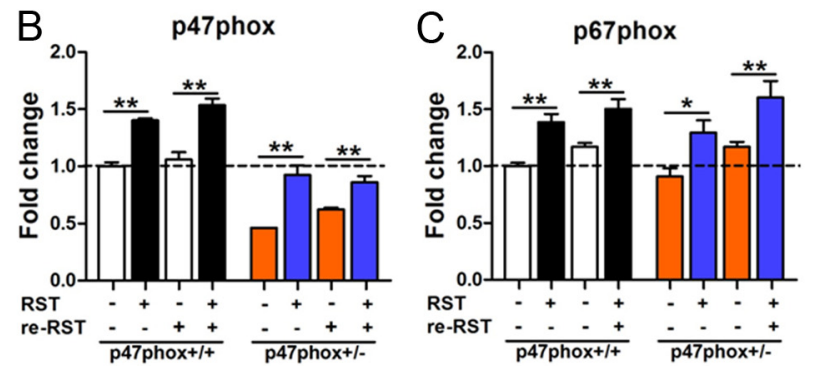
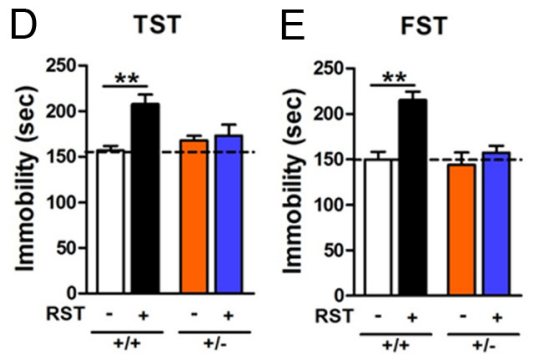

G
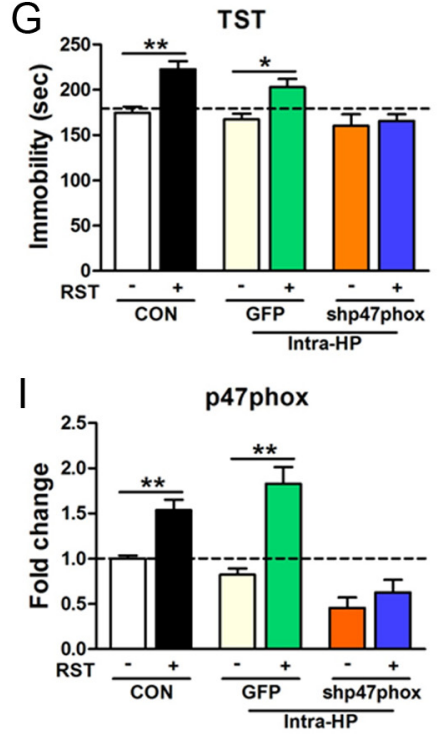

$\mathrm{H}$
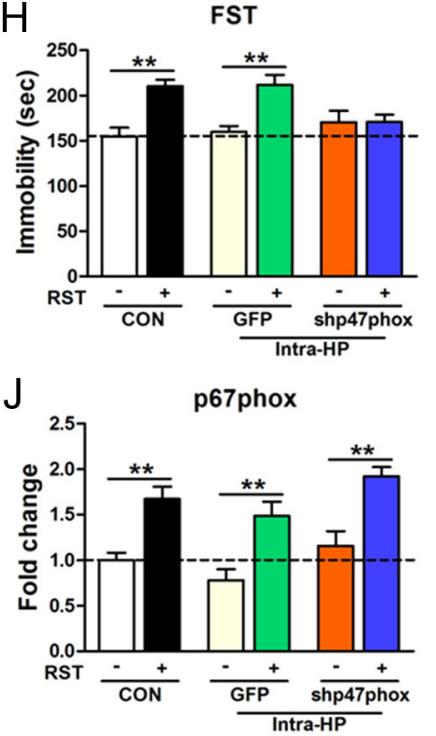

Figure 7. Molecular or genetic targeting of p47phox suppressed developing depressive behavior. $A$, Experimental design for restraint treatment and behavioral tests. Restress was given from poststress day 21. $\boldsymbol{B}, \boldsymbol{C}$, Expression of p47phox $(\boldsymbol{B})$ and p67phox $(\boldsymbol{C})$ in the hippocampus of heterozygous p47phox knock-out mice $(+/-)$ and their wild-type control $(+/+)$ at the end of the $2 \mathrm{~h}$ $\times 14 \mathrm{~d}$ stress or the $2 \mathrm{~h} \times 3 \mathrm{~d}$ restress $(n=6-9)$. Tw0-way ANOVA and Bonferroni post hoc tests; for $p 47$ phox expression levels, significant effects of genotype $\left[F_{(1,52)}=221.9, p<0.0001\right]$ and restraint $\left[F_{(3,52)}=42.34, p<0.0001\right]$ and no interaction between genotype and RST $\left[F_{(3,52)}=2.117, p=0.1093\right]$. For p67phox expression levels, significant effects of restraint $\left[F_{(3,52)}=18.41\right.$, $p<0.0001]$, but no effect of genotype $\left[F_{(1,52)}=0.1280, p=0.7220\right]$ and no interaction $\left[F_{(3,52)}=0.5948, p=0.6213\right]$. $\boldsymbol{D}, \boldsymbol{E}$, Behavioral performance in TST $(\boldsymbol{D})$ and $\mathrm{FST}(\boldsymbol{E})$ displayed by heterozygous p47phox knock-out mice ( $+/-$ ) and their wild-type control $(+/+)$, after $2 \mathrm{~h} \times 14 \mathrm{~d}$ stress $(n=5-12)$. Tw0-way ANOVA and Bonferroni post hoc tests; significant effects of restraint $\left[F_{(1,34)}=6.690, p<0.05\right]$ and significant interaction between genotype and RST $\left[F_{(1,34)}=4.455, p<0.05\right]$ in TST; significant effects of restraint $\left[F_{(1,37)}=15.86, p<0.001\right]$ and significant interaction between genotype and RST $\left[F_{(1,37)}=6.919, p<0.05\right]$ in FST. $F$, Experimental design for infusion of Lenti p47phox-shRNA, restraint treatment, and behavioral tests. Lenti vector was infused into both hippocampi. GFP image (bottom). $\mathbf{G}, \boldsymbol{H}$ Behavioral performance in TST ( $\boldsymbol{G}$ ) and FST $(\boldsymbol{H})$ displayed by mice injected with Lenti p47phox-shRNA or Lenti GFP in the hippocampus, before and after $2 \mathrm{~h} \times 14 \mathrm{~d}$ stress $(n=5-9)$. Two-way ANOVA and Bonferroni post hoc tests; significant effect of restraint $\left[F_{(1,38)}=18.10, p<0.0001\right.$ for TST and $F_{(1,40)}=21.63, p<0.0001$ for FST], and significant interaction between genotype and RST $\left[F_{(2,38)}=3.323, p<0.05\right.$ for TST and $F_{(2,40)}=5.350, p<0.01$ for FST]. CON, noninjected control; GFP, mice injected with Lenti vector; shp47phox, mice injected with Lenti p47phox-shRNA; Intra-HP, intrahippocampal injection. $I, J$, Expression of p47phox $(I)$ and p67phox $(J)$ in the hippocampus before and after $2 \mathrm{~h} \times 14 \mathrm{~d}$ stress ( $n=6$ animals for each group). CON, noninjected control; GFP, mice injected with Lenti vector; shp47phox, mice injected with Lenti p47phox-shRNA; Intra-HP, intrahippocampal injection. Two-way ANOVA and Bonferroni post hoc test; significant effect of restraint $\left[F_{(1,30)}=34.79, p<0.0001\right.$ for p47phox and $F_{(1,30)}=46.46, p<0.0001$ for p67phox $]$, and significant interaction between genotype and RST for p47phox $\left[F_{(2,30)}=6.176, p<0.01\right]$, but no interaction between genotype and RST for p67phox $\left[F_{(2,30)}=0.06057, p=0.9413\right]$. Data are presented as the means \pm SEM. ${ }^{*}$ and ${ }^{* *}$ denote differences from the respective control at $p<0.05$ and $p<0.01$, respectively.

reinforced after repeated stress as evidenced by the finding that stress-induced ROS surge was exaggerated to the weak restress (2 $\mathrm{h} \times 3 \mathrm{~d}$ restraint) applied in the poststress period (Fig. $1 \mathrm{E}$ ), and that mice treated with the $2 \mathrm{~h} \times 14 \mathrm{~d}$ restraint showed inflated expression of $\mathrm{p} 47$ phox in response to restress (Fig. $6 A, B$ ). It is also noteworthy that the treatment with apocynin in the poststress period reversed depressive behavior (Fig. 6E-H). These results, together with the molecular genetic evidence (Fig. 7A-E), suggest that NADPH oxidase may be a good therapeutic target for controlling depression.

Possible mechanism of enhanced activity of NADPH oxidase in long-lasting depressive behavior

Despite the evidence that NADPH oxidase plays a pivotal role in developing and maintaining depression, questions still remain as to how NADPH oxidase produces such behavior. Several possibilities can be suggested. First, NADPH oxidase and/or oxidative stress might promote depressive behavior through transcriptional alteration of target genes, although the detailed mechanism in psychiatric illness is poorly understood. Oxidative stressinduced genetic and epigenetic alterations (Shi and Gibson, 2007; Han et al., 2008; Brown and Griendling, 2009; Roth et al., 2011; Ziech et al., 2011) could occur in the expression of key molecules regulating the limbic system. After stress, the expressions of the key components of NADPH oxidase and other ROS-related genes were altered in the limbic system, including the hippocampus (SJ Seo, JY Park, J Choi, and PL Han, unpublished observation). Recent studies with animal models showed that NADPH oxidase is a key factor in NMDA receptor-dependent synaptic plasticity and in learning and memory behavior (Kishida et al., 2005, 2006; Brennan et al., 2009; Massaad and Klann, 2011). In this context, it will be interesting to test the possibility that the depression phenotype induced by $2 \mathrm{~h} \times 14 \mathrm{~d}$ stress is related to a learned behavior reacting to repeated restraints. 
Second, repeated ROS production might occur because high ROS causes neuronal atrophy in the brain. Exposure of rodents to $10-21 \mathrm{~d}$ of restraints results in dendritic atrophy of hippocampal neurons (Watanabe et al., 1992; Magariños and McEwen, 1995; Liu et al., 1996) and the prefrontal cortex (Cook and Wellman, 2004; Radley et al., 2004). Administration of exogenous GCs produces similar neuronal loss and neurodegeneration (Magariños et al., 1998; Sousa et al., 1999) and depression (Zhao et al., 2008), and has been associated with cognitive impairment (Schaaf et al., 1999). These results are consistent with the notion that stressinduced and/or GC-induced ROS burst causes a structural change in the limbic system, which might be the mechanism that leads to long-lasting behavioral change.

In conclusion, the results of the present study suggest that repeated stress imposes persistent forms of depression signatures in the brain, leading to long-lasting depression. Although the usefulness of our stress-induced depression model to dissect the diverse spectrum of human depression has not been proven, the mechanism unraveled from this study will direct future studies about more complex mechanisms of depression. A better understanding of proper intervention at the levels of the induction and maintenance phases of depression will accelerate development of a strategy for treatment of depression.

\section{References}

Banes AK, Shaw SM, Tawfik A, Patel BP, Ogbi S, Fulton D, Marrero MB (2005) Activation of the JAK/STAT pathway in vascular smooth muscle by serotonin. Am J Physiol Cell Physiol 288:C805-C812.

Bedard K, Krause KH (2007) The NOX family of ROS-generating NADPH oxidases: physiology and pathophysiology. Physiol Rev 87:245-313.

Berton O, McClung CA, Dileone RJ, Krishnan V, Renthal W, Russo SJ, Graham D, Tsankova NM, Bolanos CA, Rios M, Monteggia LM, Self DW, Nestler EJ (2006) Essential role of BDNF in the mesolimbic dopamine pathway in social defeat stress. Science 311:864-868.

Brennan AM, Suh SW, Won SJ, Narasimhan P, Kauppinen TM, Lee H, Edling Y, Chan PH, Swanson RA (2009) NADPH oxidase is the primary source of superoxide induced by NMDA receptor activation. Nat Neurosci 12:857-863.

Brown DI, Griendling KK (2009) Nox proteins in signal transduction. Free Radic Biol Med 47:1239-1253.

Buettner GR (2011) Superoxide dismutase in redox biology: the roles of superoxide abs hydrogen peroxide. Anticancer Agents Med Chem 11:341-346.

Choi BH, Hur EM, Lee JH, Jun DJ, Kim KT (2006) Protein kinase Cdelta-mediated proteasomal degradation of MAP kinase phosphatase-1 contributes to glutamate-induced neuronal cell death. J Cell Sci 119:1329-1340.

Cook SC, Wellman CL (2004) Chronic stress alters dendritic morphology in rat medial prefrontal cortex. J Neurobiol 60:236-248.

Covington HE 3rd, Maze I, LaPlant QC, Vialou VF, Ohnishi YN, Berton O, Fass DM, Renthal W, Rush AJ 3rd, Wu EY, Ghose S, Krishnan V, Russo SJ, Tamminga C, Haggarty SJ, Nestler EJ (2009) Antidepressant actions of histone deacetylase inhibitors. J Neurosci 29:11451-11460.

Fontella FU, Siqueira IR, Vasconcellos AP, Tabajara AS, Netto CA, Dalmaz C (2005) Repeated restraint stress induces oxidative damage in rat hippocampus. Neurochem Res 30:105-111.

Graham SP, Earley RL, Guyer C, Mendonça MT (2011) Innate immune performance and steroid hormone profiles of pregnant versus nonpregnant cottonmouth snakes (Agkistrodon piscivorus). Gen Comp Endocrinol 174:348-353.

Grillo CA, Piroli GG, Rosell DR, Hoskin EK, Mcewen BS, Reagan LP (2003) Region-specific increases in oxidative stress and superoxide dismutase in the hippocampus of diabetic rats subjected to stress. Neuroscience 121:133-140.

Ha HY, Kim JB, Cho IH, Joo HJ, Kim KS, Lee KW, Sunwoo H, Im JY, Lee JK, Hong JH, Han PL (2008) Morphogenetic lung defects of JSAP1deficient embryos proceeds via the disruptions of the normal expressions of cytoskeletal and chaperone proteins. Proteomics 8:1071-1080.
Halliwell B (2006) Oxidative stress and neurodegeneration: where are we now? J Neurochem 97:1634-1658.

Han ES, Muller FL, Pérez VI, Qi W, Liang H, Xi L, Fu C, Doyle E, Hickey M, Cornell J, Epstein CJ, Roberts LJ, Van Remmen H, Richardson A (2008) The in vivo gene expression signature of oxidative stress. Physiol Genomics 34:112-126.

Huang CK, Zhan L, Hannigan MO, Ai Y, Leto TL (2000) P47(phox)deficient NADPH oxidase defect in neutrophils of diabetic mouse strains, C57BL/6J-m db/db and db/ +. J Leukoc Biol 67:210-215.

Im JY, Kim D, Paik SG, Han PL (2006) Cyclooxygenase-2-dependent neuronal death proceeds via superoxide anion generation. Free Radic Biol Med 41:960-972.

Kim KS, Han PL (2006) Optimization of chronic stress paradigms using anxiety- and depression-like behavioral parameters. J Neurosci Res 83:497-507.

Kim KS, Han PL (2009) Mice lacking adenylyl cyclase-5 cope badly with repeated restraint stress. J Neurosci Res 87:2983-2993.

Kim KS, Lee KW, Baek IS, Lim CM, Krishnan V, Lee JK, Nestler EJ, Han PL (2008) Adenylyl cyclase-5 activity in the nucleus accumbens regulates anxiety-related behavior. J Neurochem 107:105-115.

Kim KS, Kwon HJ, Baek IS, Han PL (2012) Repeated short-term (2 h×14 d) emotional stress induces lasting depression-like behavior in mice. Exp Neurobiol 21:16-22.

Kishida KT, Pao M, Holland SM, Klann E (2005) NADPH oxidase is required for NMDA receptor-dependent activation of ERK in hippocampal area CA1. J Neurochem 94:299-306.

Kishida KT, Hoeffer CA, Hu D, Pao M, Holland SM, Klann E (2006) Synaptic plasticity deficits and mild memory impairments in mouse models of chronic granulomatous disease. Mol Cell Biol 26:5908-5920.

Krishnan V, Nestler EJ (2008) The molecular neurobiology of depression. Nature 455:894-902.

Lambeth JD (2004) NOX enzymes and the biology of reactive oxygen. Nat Rev Immunol 4:181-189.

Lee KW, Kim JB, Seo JS, Kim TK, Im JY, Baek IS, Kim KS, Lee JK, Han PL (2009) Behavioral stress accelerates plaque pathogenesis in the brain of Tg2576 mice via generation of metabolic oxidative stress. J Neurochem 108:165-175.

Linares V, Sánchez DJ, Bellés M, Albina L, Gómez M, Domingo JL (2007) Prooxidant effects in the brain of rats concurrently exposed to uranium and stress. Toxicology 236:82-91.

Liu J, Wang X, Shigenaga MK, Yeo HC, Mori A, Ames BN (1996) Immobilization stress causes oxidative damage to lipid, protein, and DNA in the brain of rats. FASEB J 10:1532-1538.

Madrigal JL, Olivenza R, Moro MA, Lizasoain I, Lorenzo P, Rodrigo J, Leza JC (2001) Glutathione depletion, lipid peroxidation and mitochondrial dysfunction are induced by chronic stress in rat brain. Neuropsychopharmacology 24:420-429.

Magariños AM, McEwen BS (1995) Stress-induced atrophy of apical dendrites of hippocampal CA3c neurons: comparison of stressors. Neuroscience 69:83-88.

Magariños AM, Orchinik M, McEwen BS (1998) Morphological changes in the hippocampal CA3 region induced by noninvasive glucocorticoid administration: a paradox. Brain Res 809:314-318.

Massaad CA, Klann E (2011) Reactive oxygen species in the regulation of synaptic plasticity and memory. Antioxid Redox Signal 14:2013-2054.

McIntosh LJ, Hong KE, Sapolsky RM (1998) Glucocorticoids may alter antioxidant enzyme capacity in the brain: baseline studies. Brain Res 791:209-214.

Miao L, St Clair DK (2009) Regulation of superoxide dismutase genes: implications in disease. Free Radic Biol Med 47:344-356.

Min JK, Kim JM, Li S, Lee JW, Yoon H, Ryu CJ, Jeon SH, Lee JH, Kim JY, Yoon HK, Lee YK, Kim BH, Son YS, Choi HS, Lim NK, Kim DG, Hong HJ (2010) L1 cell adhesion molecule is a novel therapeutic target in intrahepatic cholangiocarcinoma. Clin Cancer Res 16:3571-3580.

Nestler EJ, Hyman SE (2010) Animal models of neuropsychiatric disorders. Nat Neurosci 13:1161-1169.

Pérez-Nievas BG, García-Bueno B, Caso JR, Menchén L, Leza JC (2007) CORT as a marker of susceptibility to oxidative/nitrosative cerebral damage after stress exposure in rats. Psychoneuroendocrinology 32:703-711.

Pittenger C, Duman RS (2008) Stress, depression, and neuroplasticity: a convergence of mechanisms. Neuropsychopharmacology 33:88-109.

Radley JJ, Sisti HM, Hao J, Rocher AB, McCall T, Hof PR, McEwen BS, 
Morrison JH (2004) Chronic behavioral stress induces apical dendritic reorganization in pyramidal neurons of the medial prefrontal cortex. Neuroscience 125:1-6.

Reagan LP, Magariños AM, Yee DK, Swzeda LI, Van Bueren A, McCall AL, McEwen BS (2000) Oxidative stress and HNE conjugation of GLUT3 are increased in the hippocampus of diabetic rats subjected to stress. Brain Res 862:292-300.

Rhee SG, Chae HZ, Kim K (2005) Peroxiredoxins: a historical overview and speculative preview of novel mechanisms and emerging concepts in cell signaling. Free Radic Biol Med 38:1543-1552.

Roth TL, Zoladz PR, Sweatt JD, Diamond DM (2011) Epigenetic modification of hippocampal Bdnf DNA in adult rats in an animal model of posttraumatic stress disorder. J Psychiatr Res 45:919-926.

Sahin E, Gümüşlü S (2004) Alterations in brain antioxidant status, protein oxidation and lipid peroxidation in response to different stress models. Behav Brain Res 155:241-248.

Sato H, Takahashi T, Sumitani K, Takatsu H, Urano S (2010) Glucocorticoid generates ROS to induce oxidative injury in the hippocampus, leading to impairment of cognitive function of rats. J Clin Biochem Nutr 47:224-232.

Schaaf MJ, Sibug RM, Duurland R, Fluttert MF, Oitzl MS, De Kloet ER, Vreugdenhil E (1999) Corticosterone effects on BDNF mRNA expression in the rat hippocampus during morris water maze training. Stress 3:173-183.

Schiavone S, Sorce S, Dubois-Dauphin M, Jaquet V, Colaianna M, Zotti M, Cuomo V, Trabace L, Krause KH (2009) Involvement of NOX2 in the development of behavioral and pathologic alterations in isolated rats. Biol Psychiatry 66:384-392.

Seo JS, Lee KW, Kim TK, Baek IS, Im JY, Han PL (2011) Behavioral stress causes mitochondrial dysfunction via $\mathrm{ABAD}$ up-regulation and aggra- vates plaque pathology in the brain of a mouse model of Alzheimer disease. Free Radic Biol Med 50:1526-1535.

Serrano F, Kolluri NS, Wientjes FB, Card JP, Klann E (2003) NADPH oxidase immunoreactivity in the mouse brain. Brain Res 988:193-198.

Shi Q, Gibson GE (2007) Oxidative stress and transcriptional regulation in Alzheimer's disease. Alzheimer Dis Assoc Disord 21:276-291.

Sousa N, Paula-Barbosa MM, Almeida OF (1999) Ligand and subfield specificity of corticoid-induced neuronal loss in the rat hippocampal formation. Neuroscience 89:1079-1087.

Tammariello SP, Quinn MT, Estus S (2000) NADPH oxidase contributes directly to oxidative stress and apoptosis in nerve growth factor-deprived sympathetic neurons. J Neurosci 20:RC53.

Tejada-Simon MV, Serrano F, Villasana LE, Kanterewicz BI, Wu GY, Quinn MT, Klann E (2005) Synaptic localization of a functional NADPH oxidase in the mouse hippocampus. Mol Cell Neurosci 29:97-106.

Temple MD, Perrone GG, Dawes IW (2005) Complex cellular responses to reactive oxygen species. Trends Cell Biol 15:319-326.

Tsiakitzis K, Kourounakis AP, Tani E, Rekka EA, Kourounakis PN (2005) Stress and active oxygen species-effect of alpha-tocopherol on stress response. Arch Pharm (Weinheim) 338:315-321.

Watanabe Y, Gould E, McEwen BS (1992) Stress induces atrophy of apical dendrites of hippocampal CA3 pyramidal neurons. Brain Res 588:341-345.

Zafir A, Banu N (2009) Modulation of in vivo oxidative status by exogenous CORT and restraint stress in rats. Stress 12:167-177.

Zhao Y, Ma R, Shen J, Su H, Xing D, Du L (2008) A mouse model of depression induced by repeated corticosterone injections. Eur J Pharmacol 581:113-120.

Ziech D, Franco R, Pappa A, Panayiotidis MI (2011) Reactive oxygen species (ROS)-induced genetic and epigenetic alterations in human carcinogenesis. Mutat Res 711:167-173. 